\title{
The Majesty of Courage in a Society
}

\author{
Laurence Thomas* \\ Political Science and Philosophy, Syracuse University, USA
}

Submission: August 20, 2018; Published: August 29, 2018

*Corresponding author: Laurence Thomas, Political Science and Philosophy, Syracuse University, USA, Tel: (315) 443-5824; Email: Ithomas@syr.edu

\section{Keywords: Courage; Society; Realization; Horrifically; Freedom; Human being; Tremendous; Persistence; Ratiocination; Articulated; Language}

\section{Opinion}

I define courage as the wherewithal to do the right thing notwithstanding the significant risks that one takes because of doing so. And it is obvious that there are degrees of courage. Thus, two people can be courageous, yet it is clearly the case that one individual is substantially more courageous than the other. For instance, Bernice may be absolutely determined to put her very life on the line to protect an innocent person from being killed. By contrast, although Maji has the strength of character to be honest and forthright, there is no circumstances under which Maji is willing to risk his life to help another who is being horrifically attacked. The two examples tell us what we already know, namely that courage admits of degrees. On the one hand, there can be no doubt whatsoever that in general the typical morally decent human being should have a measure of courage. On the other, it is quite clear that if a person's standing up to evil requires that the individual puts her or his very life on the line, it is ever so obvious that a great many human beings lack that level of courage. And if that is the case, then we have a very poignant explanation regarding the persistence of evil throughout the world.

The significance of the point made at the end of the preceding paragraph is ever so poignant, namely that evil is accorded a measure of "freedom" in a society if far too many individuals in that society lack the wherewithal to stand up to evil. And it is that truth which ever so significantly speaks to the importance of courage. No society can be the kind of society that it should be if to a considerable degree genuine courage is lacking in that society.

Thus, it is one thing for an individual to say that she or he has courage. And it is quite another for it to be the case that saidindividual exhibits behavior which makes unequivocally clear that she or he has considerable amount of courage. performs an act that is clear a very solid indication that she or he has genuine courage. As is no doubt obvious, the appropriate experience is absolutely of the utmost importance in terms of an individual justifiably believing that she or has genuine courage. No amount of sheer ratiocination will suffice as meaningful evidence that a person has genuine courage. Indeed, while a person may have the belief that she or he would exhibit tremendous courage should the circumstances call for doing so, the evidence is overwhelming that the appropriate experience is necessary for a person to be truly justified in believing that she or he has such courage. We have an analogous scenario with a person speaking a foreign language. The very best evidence that a person was raised in a country in which the Alpha language is spoken is none other than the fact that said-individual is clearly quite capable of speaking the Alpha language, which means that the individual will often grasp the point of what is being said before the point has been fully articulated.

To state the obvious. It is manifestly obvious that no amount of sheer ratiocination constitutes a reasonable indication that a person is a competent speaker a language. Likewise, no amount of sheer ratiocination constitutes a reasonable indication that a person has a non-trivial measure of courage. It is obvious that if an individual is a competent speaker of a language, then it will often be the case that the individual can see the point that a speaker is concerned to make well before the speaker has finished making the point. The point just made holds mutatis mutandis with respect to a person who is indeed courageous. For being courageous is not just about being willing to fight or tremendously criticize another because one disapproves of the individual's behavior. Quite the contrary. Being courageous is very much about endeavoring to recognize what exactly is the issue that resulted in an individual's ever so unexpected violent behavior and seeking to determine whether that issue can address in a satisfactory manner. In other words, being genuinely courageous requires having a considerable measure of self-command (to use the term introduced by Adam Smith in his work A Theory of Moral Sentiments. And to have self-command is to have the wherewithal to do the right thing, notwithstanding the temptations or feelings that one might have to act otherwise. 
Thus, having self-command is ever so fundamental to being genuinely successful. For when we see that a change is in order, then our having a deep measure of self-command enables us to bring about the realization of the change that needs to be made. Thus, self-command is absolutely a major factor in terms of being courageous. And that is precisely because there can be no genuine courage in the absence of a deep commitment to do what is morally appropriate-a commitment that one is ever determined to have even if others do not have it.
Finally, constructive self-reflection is absolutely a fundamental part of being truly courageous. Such is the case precisely because there can be no genuine courage if a person is lacking in clarity regarding both the excellences and the shortcomings of her or his behavior. Thus, genuine courage is not just about how we treat others. It is also very much about how we treat ourselves.

\section{Your next submission with Juniper Publishers} will reach you the below assets

- Quality Editorial service

- Swift Peer Review

- Reprints availability

- E-prints Service

- Manuscript Podcast for convenient understanding

- Global attainment for your research

- Manuscript accessibility in different formats

( Pdf, E-pub, Full Text, Audio)

- Unceasing customer service

Track the below URL for one-step submission https://juniperpublishers.com/online-submission.php 